\title{
Effects of Moringa oleifera Leaves and Lysine on Growth Performance of Broiler Chicks
}

\author{
Ufele Angela Nwogor ${ }^{*}$, Orji Chizoba Ndidiamaka \\ Zoology Department, Faculty of Biosciences Nnamdi Azikiwe University, Awka, Nigeria
}

Email address:

ufeleangel@yahoo.com (U. A. Nwogor)

${ }^{*}$ Corresponding author

To cite this article:

Ufele Angela Nwogor, Orji Chizoba Ndidiamaka. Effects of Moringa oleifera Leaves and Lysine on Growth Performance of Broiler Chicks. Advances in Applied Physiology. Vol. 4, No. 1, 2019, pp. 1-4. doi: 10.11648/j.aap.20190401.11

Received: August 9, 2018; Accepted: August 29, 2018; Published: March 26, 2018

\begin{abstract}
An experimental research was carried out to evaluate the effects of Moringa oleifera leaves and lysine on the growth performance of broiler chicks. A total of 60 three-week old broiler chicks were used in this study. The chicks were randomly assigned to four dietary treatments; T1 (control) having 0kg Moringa oleifera and 0kg lysine inclusion, T2 had $0.25 \mathrm{~kg}$ of lysine with no Moringa oleifera, T3 had $0.25 \mathrm{~kg}$ of Moringa oleifera with no lysine and T4 had $0.5 \mathrm{~kg}$ of Moringa oleifera and no lysine respectively. Each treatment was replicated thrice in a completely randomized design. The experiment lasted for 10 weeks during which the parameters monitored included weight, organ weights and carcass characteristics. The data collected were subjected to analysis of variance and LSD at 5\% significant level. The highest weight gain was recorded in the broiler chicks fed with diet T4 $(2.04 \mathrm{~kg})$ followed by those fed with diet T2 $(20.13 \mathrm{~kg})$ while the least was recorded in those fed with diet T1 $(15.79 \mathrm{~kg})$. The analysis of variance result revealed that there was significant difference $(\mathrm{p}<0.05)$ between the weight gain of broiler chicks fed with the four dietary treatments for 10 weeks. The specific growth rate of broiler chicks fed with diet $\mathrm{T} 4$ had the highest specific growth rate (2.23) followed by those fed with diet T3 (2.20) while the lowest was diet T2 (1.96). But no significant difference existed between the specific growth rates of the birds fed the four diets. It was concluded that Moringa oleifera leaves can serve as a major component of poultry ingredients as it contains high protein content, cheap and readily available.
\end{abstract}

Keywords: Broiler Chicks, Moringa oleifera, Lysine and Growth

\section{Introduction}

The growth of the national economy has been significantly affected by poultry [1]. Poultry encompasses a number of domesticated avian species such as the chicken reared for laying eggs (layer) or broilers (reared for meat production), turkey, game birds, ducks and other water fowls. It is also the promising source of additional income and means of quick returns from investment [2]. It is pertinent to note that about $10 \%$ of Nigerian population is engaged in poultry production making broiler production a rapid growing agricultural business [3]. Animal protein demand and supply gap among Nigerians has continued to widen, resulting in sub-optimal animal protein intake and consequently predisposing the people to deplorable animal protein malnutrition [4].

Malnutrition is the major challenge in Nigeria as most of Nigerian diets are deficient in animal protein [5]. Hence, the demand for protein of animal origin in Nigeria is greater than its supply [6]. Developing the poultry industry is one of the fastest means of boosting animal protein supply [2]. This is as a result of their short generation interval, efficiency of nutrient transformation into high quality protein and increased rate of reproduction [7]. In Nigeria, poultry meat and eggs, offer considerable potential for meeting human needs for dietary animal supply [8].

Poultry meat which belongs to a group of white meat has low fat myoglobin content, which is responsible for its color. This white meat produces glycogen, a polysaccharide which plays an important role in the glucose cycle. It is a source of lean protein for people with heart and cholesterol problems [9]. Despite its ability to boost the physical and mental development of youth and labour force in Nigeria, its consumption rate is still low [10]. This problem of low level intake of animal protein (especially poultry meat) can be solved if massive efforts will be geared towards poultry production [11]. 
Consequently, research reports show that feed is a critical input in monogastric production [12]. Poultry production has been constrained by the high cost of conventional protein and energy sources and inadequate feed supply [13, 14]. This high cost of broiler feed production has declined participation in poultry production. It therefore becomes imperative to search for locally available alternative sources of protein for use as feed supplement to poultry [1].

The utilization of leaf meal protein as one of the protein sources is gaining increased research interest [15]. For instance the studies on effect of the leaves of Chromolaena odorata [4] and Moringa oleifera [16] on performance and haematological parameters has been carried out. $M$. oleiferais one of the herbs that could substitute synthetic growth enhancers and supplements (including lysine) in broiler production. Literature has shown its potential in the performance of broilers given $M$. oleifera leaf extract. The leaf extract led to the improvement of feed consumption, daily weight gain, final weight and profit compared to the control group [17]. The leaves of M. oleifera are potentially inexpensive protein for livestock feeding [18], containing $80 \%$ dry matter, $29.7 \%$ crude protein, $22.5 \%$ crude fibre, $4.38 \%$ ether extract, $27.8 \%$ calcium and $0.26 \%$ phosphorus [19].

\section{Materials and Methods}

\subsection{Procurement of Experimental Animal}

A total of 60 broiler chicks at three weeks old were used for the experiment. The birds were randomly selected into four (4) treatment groups of five birds each. The stocking density is five birds per meter square. Each group was replicated three times. The animals were maintained under standard laboratory condition, that is, a well aerated room with alternating, light and dark cycle of 12 hours each. They were allowed to acclimatize with the environment for one week before the commencement of the experiment. That is before using weighing balance to check the weight.

\subsection{Experimental Treatments}

The broiler chicks used for the experiment were randomly assigned to four treatments. The diets were prepared and separated according to the treatments. Treatment 1 (served as control), this diet had no inclusion of lysine and Moringa oleifera, this was given to birds in cage A. Treatment 2 contained $0.25 \mathrm{~kg}$ of lysine with no Moringa oleifera, this was given to birds in cage B. Treatment 3 contained $0.25 \mathrm{~kg}$ of Moringa oleifera with no lysine this was given to birds in cage C. Treatment 4 contained $0.5 \mathrm{~kg}$ of Moringa oleifera and no lysine, this was given to birds in cage $\mathrm{D}$. The birds were fed twice daily at 8:00am and 6:00pm throughout the period of study. The experiment lasted for ten weeks.

\subsection{Data Analysis}

The weight of the broiler chicks was taken weekly using a sensitive weighing balance. The result of the experiment was analyzed using Analysis of variance (ANOVA). The comparison of mean was separated using a post Hoc test (Least Significant Difference), [20].

\section{Results}

Figure 1 below shows the mean weight gain of broiler chicks fed with different dietary treatments, T4 having the highest weight gain followed by T2. T1 had the leastmean weight gain.

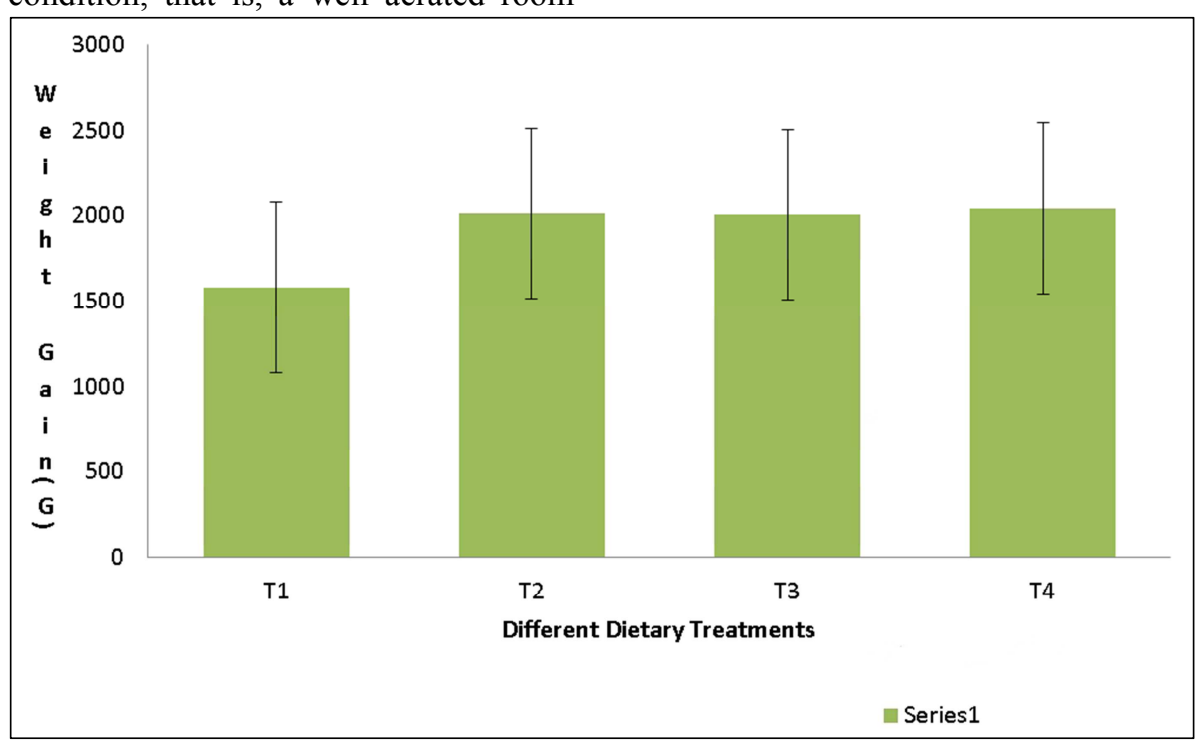

Figure 1. Mean Weight gain of broiler chicks fed with different diet treatment.

Table 1 and figure 2 below show the result on the specific growth rate of broiler chicks fed with $M$. oleiferaleaves and lysine (different dietary treatments). Table 1 reveals that the specific growth rate of broiler chicks fed with diet T4 diet had the highest specific growth rate $(2.23 \mathrm{~g} \%$ /day $)$ followed by diet T3 (2.20 g\%/day) while lowest in diet T2 (1.96 g\%/day). 


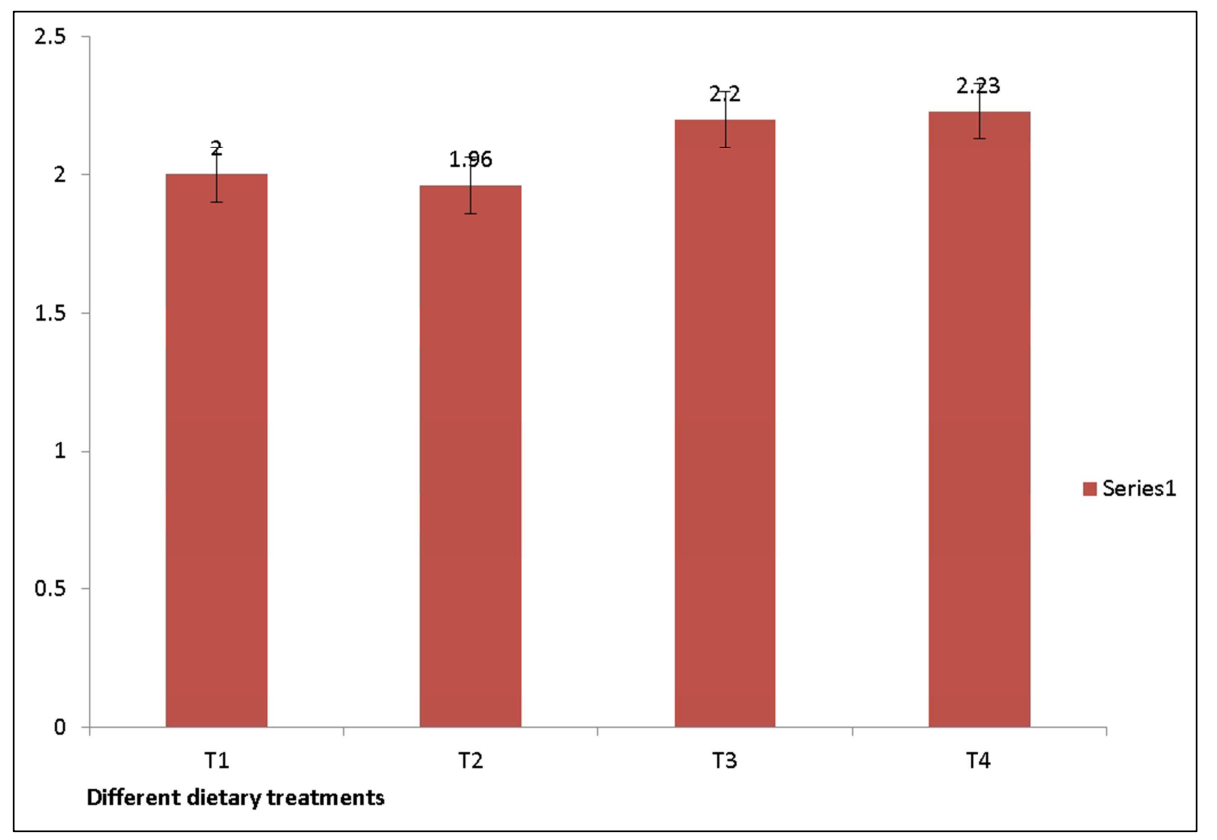

Figure 2. \% specific growth rate of broiler chicks.

Table 1. Specific Growth Rate of Broiler Chicks Fed with M. oleifera Leaves and Lysine Supplements for 10 weeks.

\begin{tabular}{llll}
\hline Treatments & Loge $\mathbf{W}_{\mathbf{1}}$ & LogeW & SGR $(\mathbf{g} \% /$ day $)$ \\
\hline T1 & 6.25 & 7.65 & 2.00 \\
T2 & 6.25 & 7.62 & 1.96 \\
T3 & 6.30 & 7.84 & 2.20 \\
T4 & 6.28 & 7.84 & 2.23 \\
\hline
\end{tabular}

\section{Discussion}

The broilers fed with diet T4 ( $0.5 \mathrm{~kg}$ of $M$. oleifera leaves) showed significantly higher weight gain than other treatments. This indicates that $M$. oleifera has enhanced effect on weight gain of the broilers. The findings of this study also revealed that specific growth rate of broilers fed with diet T4 $(0.5 \mathrm{~kg}$ of M.oleifera leaves only) were significantly higher than those fed with other diet treatments. This result is sequel to previous findings by [19] and [21] who mentioned that the inclusion of M. oleifera leaf meal in the diet of the broilers significantly $(p<0.05)$ enhanced their weight gain at $1 \%$ level which was significantly higher than the control. Similarly, [16] reported that chicks fed with moringa-based diet performed significantly $(p<0.05)$ better than the birds of the control group in terms of higher weight gain and feed conversion ratio. This current study also corroborates the report of [22] on high performance of birds fed moringa-based diet. The rich content of nutrients $[18 ; 19]$ and antimicrobial properties of $M$. oleifera [23] may be responsible for these findings. M.oleifera was also reported to have a natural enzyme which aid digestion of fibrous food in animals [24]. In addition, [25] reported that Moringa oleifera leaf meal can replace protein source (soyabean and groundnut cake) up to $10 \%$ in broiler diets without any adverse effects on growth. Furthermore, the broilers fed with diet $\mathrm{T} 1$ was significantly lower than other treatments in weight gain. This is in contrast with the report by
[26] who reported that the improved weight gain of birds fed on Moringa oleifera based diets could be attributed to higher protein content of the diets which were efficiently metabolized for growth.

\section{Conclusion and Recommendation}

The result of this research indicated that the weight gain and specific growth rate of broilers fed with diets T4 $(0.5 \mathrm{~kg}$ of M.oleifera) were significantly higher than those fed with other treatment diets. Hence, M.oleifera leaves can serve as a major component of poultry ingredients as it contains high protein content, cheap and readily available. It is therefore recommended that Moringa oleifera leaves should be incorporated in broiler feed for better growth performance.

\section{References}

[1] Ufele A. N, Ogbu A. U, Ebenebe C. I and Akunne C. E. (2015a). Effect of locally produced blood meal on growth performance and packed cell volume of broiler chicks. American Journal of Agriculture and Forestry, 3 (3):105-108.

[2] Ensminger, W. I. and Akubilo, C. O. (2002). Thermal analysis and evaluation of protein requirement of a passive solar energy poultry chick brooder in Nigeria. Journal of Renewal Energy, 9:1-7.

[3] Agbede, J. O., and Aletor, V. (2007). The performance, nutrient utilization and cost implications of feeding broiler finisher conventional or underutilized resources. Applied Tropical Agriculture, 2:57-62.

[4] Ekenyem, B. U., Obih, T. K. O., Odo, B. I. and Mba, F. I. A. (2010). Performance of finisher broiler chicks fed varying replacement levels of Chromolaenaodorata Leaf for soyabean meal. Pakistan Journal of Nutrition, 9 (6):558-561. 
[5] Ufele A. N, Okoye C. B. and Ebenebe C. I. (2015b). Effect of natural and artificial ascorbic acid supplementation on the growth performance and packed cell volume of broiler chicks. American Journal of Life Sciences, 3 (3): 158-161.

[6] Akinmutimi, A. H. and Onukwe, C. C. (2002). Effect of cooking with various concentrations of potash on nutrient composition of potash. Journal of Agriculture and Biotechnology, 1:1-3.

[7] Akinfela O., Kehinde, A. O. A. and Tewe, O. O. (1999). Performance and economy production of pigs fed whole Cassava plant based diet in the tropics. Journal of Animal Production Investigation, 2:181-186.

[8] Folorunsho O. R. and Onibi, G. E. (2005). Assessment of the nutritional quality of Eviscerated waste from selected chicken types. In: Onibi, H. G, Agele, S. O. and Adekunle, V. A. J. (eds); Proceedings of the 1st Annual Conference on Developments in Agriculture and Biological Science 27th April, 2005, Akure, Nigeria. Pp: 300.

[9] Brooks, M. C. (2001). Effect of Protein on Human Growth and Development. International Journal of Nutrition, 25: 4655 .

[10] Akinmutimi, A. H. (2004). Evaluation of sword bean (Canavaliagladiata) as an alternative feed resource for broiler chickens. Ph. D Thesis Michael Okpara University of Agriculture, Umudike, 474-475.

[11] Ezieshi, E. V, Okhueubie, I. F., Ezennabike, C. C. and Olomu, J. M. (2004). Comparative performance of broiler chicks fed graded levels of palm kernel cake and maize offal. Proceedings of the 29th Annual Conference of Nigerian Society of Animal Production. pp: 253-256.

[12] Madubuike, F. N. and Ekenyem, B. U. (2001). Non RuminantLivestock Production in the Tropic. Guest-Chicks Graphic Centre, Owerri, Nigeria, pp:196.

[13] Ahaotu, E. O, Ezeafulukwe C. F, Ayo-Enwerem C. M and Ekenyem, B. U. (2013). Effects of enzyme fortified raw moringa seed (Moringaoleifera) waste diets on nutrient utilization and haematological parameters of broilers. International Journal Applied Science Engineering, 1: 25-30.

[14] Atawodi, S. E., Mari, D., Atawodi, J. C. and Yahaya, Y. (2008). Assessment of Leucaenaleucocephala leaves as feed supplement in laying hens. African Journal of Biotechnology, 7 (3): 317-321.
[15] Onyimonyi A. E. and Onu, E. (2009). An assessment of paw paw leaf meal as protein ingredient for finishing broiler. International Journal of Poultry Science, 8 (10): 995-998.

[16] Ebenebe C. I., Umegechi, C. O., Aniebo and Nweze, (2012). Comparison of haematological parameters and weight changes of broiler chicks fed different levels of Moringaoleiferadiet. International Journal of Agriculture and Biosciences, 1 (1):23-25.

[17] Lannaon, W. J. (2007). Herbal plants as source of antibiotics for broilers. Agriculture Magazine, 11 (2): 55.

[18] Sarwatt S. V., Milangha, M. S., Lekule, F. P. and Madalla, N. (2004). Moringaoleiferaand cotton seed cake as supplements for small holder dairy cow fed napier grass. Livestock Research for Rural Development, 16: 38 - 44.

[19] Kakengi, A. M. V., Shen, M. N., Sarwart, S. V. and Fujihara, T. (2003). Can Moringaoleifera be used as protein supplement to ruminant diet? Asian-Australian Journal of Animal Science, 18 (1): 42-47.

[20] William, A. C., and George, W. S. (2008). Statistical Methods, 6th Edition, the Iowa State University Press. Ames, Iowa, USA. Pp. 167-263.

[21] Banjo, O. S. (2012). Growth and performance as affected by inclusion of Moringaoleifera leaf meal in broiler chicks diet. Journal of Biology, Agriculture and Healthcare, 9: 35-38.

[22] Ebenebe, C. I., Anigbogu, C. C., Anizoba, M. A. and Ufele, A. N. (2013). Effect of various levels of Moringa Leaf Meal on the Egg Quality of Isa Brown Breed of Layers. Advances in Life Sciences and Technology 14: 45-49.

[23] Fahey, J. W., Zakmann, A. T., and Talalay, P. (2001). The chemical diversity and distribution of glucosinolates and Isothiocyanates among plants. Corrigendum Phytochemistry, 59: 200-237.

[24] Greg, M. E. (2008). Effect of enzymes on cellulose, European Journal of Applied Microbiology Biotechnology, 40: 167 -171.

[25] Onunkwo, D. N and George, O. S (2015). Effects of Moringaoleifera leaf meal on the growth performance and carcass characteristics of broiler birds. IOSR Journal of Agriculture and Veterinary Science, 8 (3II): 63-66.

[26] El Tazi, S. M. A. (2014). Effect of feeding different levels of Moringaoleifera leaf meal on the performance and carcass quality of broiler chicks. International Journal of Science and Research, 3 (5):147-151. 